\title{
FACTORS AFFECTING THE COST OF SERVICE TRADE: EMPIRICAL EVIDENCE FROM CHINA AND THE EUROPEAN UNION
}

\author{
Ji Chen', Qiang Fang', Si Liü, Tomas Balezentis4, \\ Chonghui Zhang ${ }^{5}$
}

\footnotetext{
1 Zhejiang Gongshang University, School of Statistics and Mathematics, China, ORCID: 0000-0001-7201-9649, chenji810404@zjgsu.edu.cn;

2 Zhejiang Gongshang University, School of Statistics and Mathematics, China, ORCID: 0000-0003-4740-905X, fq18358183385@163.com;

3 Zhejiang Gongshang University, School of Statistics and Mathematics, China, ORCID: 0000-0001-6276-1735, liusi_mas@163.com;

$4 \quad$ Lithuanian Institute of Agrarian Economics, Lithuania, ORCID: 0000-0002-3906-1711, tomas@laei.lt;

5 Zhejiang Gongshang University, School of Statistics and Mathematics, China, ORCID: 0000-0002-7077-4795, zhangch1988@zjgsu.edu.cn (corresponding author).
}

\begin{abstract}
This study examines the factors affecting the cost of service trade between China and the countries of the EU. The costs between China and EU member states from 2005 to 2017 are measured using the improved gravity model. On the basis of relevant theories, the influencing factors system of service trade cost is constructed, and a dynamic panel model is used to conduct empirical analysis. The empirical results can be summarized into four aspects. First, the costs of service trade between China and EU member states has shown a general trend of gradual decline and there is still room for further decline. Second, the costs of trade in services between China and developed EU countries are lower, while those between China and undeveloped EU countries are higher. Third, service restriction, economic development levels and infrastructure have a greater impact on the cost of bilateral trade in services. Lastly, there are differences in influencing factors of service trade cost among countries with different levels of economic development.
\end{abstract}

Keywords: Service trade, trade cost, influencing factors, panel data.

JEL Classification: C33, F1, L8.

APA Style Citation: Chen, J., Fang, Q., Liu, S., Balezentis, T., \& Zhang, C. H. (2020). Factors Affecting the Cost of Service Trade: Empirical Evidence from China and the European Union. E\&M Economics and Management, 23(1), 19-33. https://doi.org/10.15240/tul/001/2020-1-002

\section{Introduction}

Trade promotes economic (Drelich-Skulska \& Domiter, 2018; Skulski, 2018; Bobowski, 2018), social (Radukic et al., 2019) and environmental (Munir \& Ameer, 2018; Tao et al., 2017) interactions. The conceptual category of service trade has two different interpretations, broad and narrow. In a narrow sense, trade in services refers to activities in which a country meets the specific needs of other countries in a way that provides direct services and is paid in the course of the transaction. In the broad service trade, it includes both tangible activities and various intangible activities that complete the transaction without direct contact between the service provider and the user. Unless otherwise stated, trade in services usually refers to concepts in a broad perspective.

A large number of empirical studies have shown that trade in services can promote national economic growth, increase total factor productivity, and promote the upgrading of industrial structure (Robinson, 2002; Weiss, 2010). Moreover, the development of trade in services can also increase the ability of countries to participate in international division of labor, 
reduce the cost of production and transactions, and raise the level of social welfare. Therefore, how to promote the development of trade in services has become one of the hot issues in this field.

In recent years, the study of the issue of service trade from the perspective of cost has emerged as a new trade. The cost of trade has already become the core content of international trade theory. It is the key to correctly understanding the location choice, industrial space gathering and corporate heterogeneity in the new and the new-new trade theories. Hummels (2001) argued that trade costs are indispensable in the construction of international trade models, and all empirical analysis results require trade costs to be verified. In addition, scholars in the field of economics have reached consensus on the importance of trade costs, Obstfeld and Rogoff (2000) considered it to be the key to open economy macroeconomics, Novy (2013) also suggested that trade costs will play a central role in building the micro-foundation of new open macroeconomics.

As one of the world's largest economic entities, the cooperation between the EU and China in international trade has been close. Statistics from the Eurostat show that the bilateral trade in services between China and the EU reached 77.3 billion euros in 2017 , an increase of $18.92 \%$.

At the same time, since the "One Belt, One Road" initiative, China's service trade cooperation with countries along the "Belt and Road" has made rapid progress. As an important member of the European Union and one of the G7 group of countries, Italy officially joined the "Belt and Road" program on March 23, 2019, which is bound to bring demonstration effects to other EU countries. All of this means that cooperation between China and EU member states will be closer and the development of trade in services will be deeper. It is therefore necessary to study the trade in services between China and the EU, which will help us understand the characteristics of bilateral service trade and provide decision support for the formulation of China-EU trade policy.

To expand the openness of the service industry and to increase the share of trade in services between China and the EU, this paper studies the cost and its factors of bilateral trade in service, and the measures to reduce the cost.

The rest of the paper is organized as follows. Section 1 reviews the research on service trade costs. A measurement method of service trade cost is introduced in Section 2. The calculation and analysis of the cost of bilateral service trade is conducted based on the trade data between China and EU member countries from 2005-2017. Drawing on relevant theories, the factors affecting the cost of bilateral service trade are explained in Section 3. An econometric model of bilateral service trade costs between China and EU member states is constructed in Section 4. We study the influencing factors of service trade cost from a holistic perspective, and analyze the influencing factors of bilateral service cost among sample countries with different economic development levels based on the grouping perspective. Conclusions and recommendations are presented in Section 5.

\section{Literature Review}

Andersen (2004) argued that trade costs refer to the sum of production costs and all other costs paid by consumers to obtain goods or services, usually including tariffs, distance costs, information costs, contract execution costs, and so on.

In the existing research, the calculation method of trade cost can be divided into two major categories: direct measurement and indirect measurement. The former has a relatively large limitation and is only applicable to certain types of trade activities. The latter includes two types: trade costs inferred from price or those inferred from trade flow.

Due to the heterogeneity of market structure between countries, the poor comparability of service prices, the difficulty of data acquisition, and so on, it is difficult to apply the inference trade cost from price when calculating the cost of bilateral service trade. Therefore, it can only be applied to the calculation of domestic trade costs. By measuring the impact of trade costs on trade flows, the scale of trade costs is derived, which is the basic step of the inference of trade cost from trade flow.

A gravity model is the theoretical basis of the inference trade cost from trade flow, for example, sees McCallum (1995) and Rose (2000). However, the traditional gravity model has two shortcomings. The first drawback is that it requires an assumption of the main 
components of trade costs, which may lead to biases in the cost estimates. The second drawback is that the traditional gravity model does not consider the impact of multilateral resistance on trade costs, leading to a lack of theoretical foundation at the micro level.

In response to the two defects mentioned above, relevant scholars have conducted extensive research on the basis of the traditional gravity model. Wincoop and Anderson (2003) and Novy (2006) incorporated multilateral resistance into the model and constructed a modified general equilibrium model, but the bilateral trade costs are set to be symmetrical. However, due to the difficulty in obtaining data such as multilateral resistance, this model cannot be used to solve the export trade cost.

Drawing on the modeling ideas of Head and Ried (2001) and Dixit-Stiglitz's increasing returns to the home market, Novy (2008) proposed a modified general equilibrium model. Based on Ricardo's comparative advantage theory and theories of heterogeneous firms and trade, Novy (2013) further improved the theoretical basis of Novy (2008) by drawing on the Easton and Kortum (2002) and Melitz and Ottaviano (2008) models. Novy (2013) not only overcomes the shortcomings of the microtheoretical foundation and the symmetry of the traditional gravity model, but also takes the basic idea of the comparative advantage and heterogenous firm trade theories into account, this model has therefore been widely used.

In recent years, research on the cost of China's service trade has gradually increased, but most research has adopted the model proposed by Novy (2013). Zhang and Jiang (2019) measured the cost of bilateral service trade between China and OECD member countries from 2000 to 2016. The results revealed that the cost of bilateral service trade is basically declining. Tu (2016) measured the bilateral service trade costs of China and its major trading partners from 1995 to 2011, and argued that the cost of bilateral service trade showed a trend of gradual decline. Wan and Rao (2017) estimated the cost of bilateral service trade between China and OECD countries from 2000 to 2014 , and analyzed the influencing factors. The results indicated that the cost of service trade between China and OECD countries is declining and has significant potential for further decline. Hao and Jiang (2019) investigated the cost of trade in services between China and 21 OECD member countries, and their conclusions are consistent with Tu (2016) and Wan and Rao (2017).

Some scholars have studied the influencing factors of service trade activities. King (2018) conducted empirical studies using Mongolia and Chinese Taipei as examples. The results revealed that information technology, diplomacy, liberalization, and privatization are the main factors affecting service trade activities. Nordas (2018) used the Nordic countries as an example to assess the relative importance of institutional, cultural, and policy issues in advancing the integration of service markets, and concluded that service market integration may be more dependent on institutional and cultural factors. Gervais (2018) estimated the impact of national policies on trade in services. The results indicated that policy barriers are an important factor affecting the scale of trade in services.

From the literature review, most of the existing literature is found to focus on the measurement of the cost of service trade, and lacks corresponding research in explaining its influencing factors. A large number of studies use the model proposed by Novy (2013) to measure the cost, but the accuracy of this method is worth discussing. Meanwhile, the dynamic changes of factors are not considered in the empirical model, and static regression methods are often used, the conclusions may therefore be questionable. In response to these problems, this study uses a sample of China and EU countries in 2005-2017 to adopt a new method to measure the cost of bilateral service trade. Based on the panel data model, the system generalized methods of moments (GMM) approach is used to analyze the main factors affecting the cost of service trade. According to the differences in economic development, a grouping model is established to discuss which factors will determine the cost of service trade in countries with different levels of economic development.

\section{Estimation of the Cost of Trade in Services between China and the EU}

\subsection{Measurement Model}

Although the method of Novy (2013) is widely used, it is difficult to fully obtain and unify the domestic trade data of trading partners, which 
increases the difficulty of measuring the cost of service trade. At the same time, it does not consider the difference between the import and export of trade costs and directly adopts their geometric mean as the estimation of service trade cost, which affects the accuracy of the calculation results.

Abulaiti (2013) followed the analytical framework of Anderson and Wincoop (2003, 2004), who assumed that Armington's (1969) world differs only by origin or producer, in which each country or economy can be treated as a company, with only the consideration of its external trading activities.

Let $c_{i j}$ and $P_{i j}$ be the quantity and price of the products imported from country $i$ to country $j$, and $\sigma$ as the elasticity of substitution across goods. The total utility of constant elasticity of substitution (CES) consumption function of country $j$ can be expressed as follows:

$$
\begin{aligned}
& \max \left(\sum_{i} c_{i j}^{\frac{\sigma-1}{\sigma}}\right)^{\frac{\sigma}{\sigma-1}} \\
& \text { s.t. } \sum_{i} P_{i j} c_{i j}=M_{j}
\end{aligned}
$$

In Formula (1), $M_{j}$ represents the total import of country $j$, which is the total expenditure of products supplied by other countries to country $j$. Assume that the world's total exports and total imports are $X_{w}$ and $M_{w}$ respectively, and the total export of country $i$ is $X_{i}$, then the following relationship is established:

$$
\begin{gathered}
X_{w}=\sum_{i} X_{i} \\
M_{w}=\sum_{j} M_{j}
\end{gathered}
$$

Therefore, according to the solution of Formula (1), the import demand function of the country $j$ for the products provided by the country $i$ is obtained, and it can be expressed as:

$$
X_{i j}=\frac{X_{i} M_{j}}{X_{w}}\left(\frac{t_{i j}}{\pi_{i} L_{j}}\right)^{1-\sigma}
$$

It should be noted that Formula (4) is equivalent to the export function of country $i$ to country $j$. In Formula (4), $X_{i j}$ represents the export of country $i$ to country $j, \pi_{i}$ represents the multilateral resistance of country $i$ in terms of exports, and $L_{j}$ represents the multilateral resistance of country $j$ in terms of imports.

Considering other countries as a whole, the world is divided into country $i$ and country $r$, so that a two-country model of international trade is established. In this case, we can get two relationships: (i) the total export of country $i$ is equal to the export of country $i$ to country $r$; (ii) the export trade cost of country $i$ is equivalent to the multilateral resistance of the country in terms of imports, and is equivalent to the multilateral resistance of country $i$ in terms of exports. It can be expressed as Formula (5) and Formula (6).

$$
\begin{aligned}
& X_{i}=X_{i r} \\
& t_{i r}=L_{r}=\pi_{r}
\end{aligned}
$$

Substituting Formula (5) into Formula (4), we can get Formula (7). Continuing to substitute Formula (6) into Formula (7) for further simplification, and the results as Formula (8).

$$
\begin{aligned}
& X_{i r}=\frac{X_{i} M_{r}}{X_{w}}\left(\frac{t_{i r}}{\pi_{i} L_{r}}\right)^{1-\sigma} \\
& \pi_{i}^{1-\sigma}=\frac{M_{w}-M_{i}}{X_{w}}
\end{aligned}
$$

Correspondingly, $L_{r}^{1-\sigma}$ can be expressed as follows:

$$
L_{r}^{1-\sigma}=\frac{X_{w}-X_{r}}{X_{w}}
$$

When expanding to multinational trade, the subscript $r$ in Formulas (7), (8), and (9) is transformed into $j$. According to the principle of balance of imports and exports, $X_{w}=M_{w}$ is established, combined with Formula (4), and we obtain:

$$
t_{i j}^{\sigma-1}=\frac{X_{i} M_{j}}{X_{i j}\left(X_{w}-M_{i}-X_{j}\right)}
$$

where $t_{i j}$ in Formula (10) represents the export cost of country $i$ to country $j$. 
Compared with Novy (2013), the trade indicators used in Formula (10) are more accessible, so the Abulaiti (2013) model is more feasible in measuring trade cost. It should be noted that the result of Formula (10) is the cost of each country's one-way export trade, not the geometric mean of bilateral import and export trade costs calculated by Novy (2013). Therefore, Formula (10) is more targeted, and the estimation of the cost of trade in services between China and EU member states is used in this study.

\subsection{Sample and Data Research Results}

Due to the limited availability of data, we select $27 \mathrm{EU}$ member states as a sample in this study. And the sample countries include Austria, Belgium, Bulgaria, Cyprus, the Czech Republic, Croatia, Denmark, Estonia, Finland, France, Germany, Greece, Hungary, Ireland, Italy, Latvia, Romania, Lithuania, Luxembourg, the Netherlands, Poland, Portugal, Slovakia, Slovenia, Spain, Sweden and Britain (Britain is still in the transition period from Europe). The data on the trade in services traded between China and EU member states is from the UN Comtrade database. The total import and export volume, bilateral trade volume and total world exports are from the World Bank's WDI database, and the data span is from 2005-2017.

\subsection{Estimation of Service Trade Costs}

This study uses a two-step approach to analyze the overall trend of service trade costs between China and the EU, and to further explore the heterogeneity of service trade costs between these. In the first step, the EU is regarded as a country and Formula (10) is used to estimate the cost of service trade between China and the EU from 2005-2017. In the second step, we measured the service trade costs between China and EU member states separately, and the results are presented in Tab. 1.

Service Trade Costs between China and the EU According to Fig. 1, the cost of trade in services between China and the EU shows a downward trend from 2005 to 2017 . During this period, the cost of trade in services fell from 1.28 in 2005 to 1.20 in 2017 , a decrease of $6.25 \%$. The service trade cost was the highest in 2005 and lowest in 2010 at 1.19 .

The trend of changes in service trade costs between China and the EU can be divided into two phases. In 2005-2010, the cost of trade in services between China and Europe declined year by year, and the overall decline was $7 \%$. In 2011, the cost of service trade rebounded and then continued its downward trend.

\section{Fig. 1: The cost of trade in services between China and the EU from 2005 to 2017}

\subsection{5}

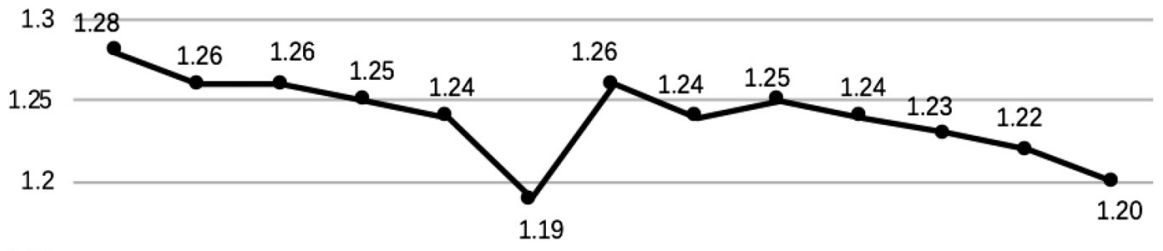

1.15

1.1

1.05

1

$\begin{array}{lllllllllllll}2005 & 2006 & 2007 & 2008 & 2009 & 2010 & 2011 & 2012 & 2013 & 2014 & 2015 & 2016 & 2017\end{array}$ 
The cause of this phenomenon can be explained by the continuing impact of the global financial crisis that erupted in 2008. In order to cope with the economic weakness caused by the financial crisis and attract more international investment and trade, China and the EU further reduced the policy barriers to service trade in 2010 , which led to a significant decline in the cost of bilateral service trade. The decline in service trade costs has led to an increase in service imports, and countries have implemented trade protection policies, such as green trade barriers to protect domestic trade. Therefore, in 2011, trade in services rebounded and increased again. In 2011-2017, the cost of service trade between China and the EU countries showed a downward trend again, with a decline of $4.8 \%$, slightly lower than the decline between 2005 and 2010, indicating that there is still room for reduction in service trade costs.

\section{Tab. 1: Cost of trade in services between China and EU member states $(\sigma=8)$}

\begin{tabular}{|c|c|c|c|c|c|c|c|c|c|c|c|c|c|c|}
\hline & 05 & 006 & 07 & 008 & 2009 & 010 & 2011 & 012 & 2013 & 2014 & 2015 & 2016 & 2017 & mean \\
\hline AIIT & & 120 & 125 & 122 & 120 & 17 & 2 & 122 & 1.26 & 118 & 21 & 1.19 & .21 & 1.22 \\
\hline Le & & 123 & 1.22 & 115 & & 12 & 1.19 & 10 & 1.28 & 129 & 1.26 & 1.29 & 1.25 & 1.22 \\
\hline $\mathrm{BC}$ & & 1. & 1.25 & 1. & 1.27 & 125 & 1 & 141 & 1.36 & 1.32 & 1.28 & 1.24 & 3 & 1.30 \\
\hline CYP & & 1.06 & 04 & 1.39 & 1.51 & .0 & 1.65 & 1.39 & 1.27 & 1.2 & 1.15 & 1.10 & .05 & 1.26 \\
\hline CZE & & 1.28 & 35 & 1.36 & 1.27 & 1.21 & 1.32 & 1.2 & 1.25 & 1.10 & (1. & 1.12 & .09 & 1.24 \\
\hline HRV & 7 & 1.22 & 1.21 & 1.28 & 1.19 & 1.47 & 1.45 & $1 . \angle 1$ & 1.32 & 1.36 & 1.26 & 1.26 & 1.24 & 1.29 \\
\hline DNK & 0 & 0.97 & 0.96 & 0.98 & 1.00 & 0.95 & 1.02 & 0.99 & 0.97 & 0.96 & 3 & 1.01 & 0.99 & 0.99 \\
\hline EST & 14 & 1.14 & 1.15 & 1.43 & 1.35 & 1.27 & 1.33 & 1.42 & 1.35 & 1.28 & 29 & 1.25 & 1.23 & 1.28 \\
\hline FIN & 09 & 1.03 & 1.04 & 1.04 & 1.02 & 0.99 & 1.05 & 104 & 1.02 & 1.03 & 4 & 1.00 & 1.00 & 1.03 \\
\hline FRA & 10 & 1.10 & 1.11 & 1.08 & 1.11 & 1.05 & 1.13 & 110 & 1.11 & 1.11 & & 1.12 & 7 & 1.10 \\
\hline $\mathrm{D}$ & & 1.15 & 1.15 & & 1.10 & & & & & & & 1.01 & & 99 \\
\hline GRC & & 1.13 & 2 & 1.24 & 1.13 & 1.12 & 4 & 1.20 & 7 & 1.26 & & 1.29 & 1 & 1.20 \\
\hline HUN & 22 & 1.20 & 24 & 1.21 & 1.23 & 22 & 1.33 & 1.32 & 31 & 1.29 & 9 & 1.25 & 1.22 & 1.26 \\
\hline IRL & 27 & 1.25 & 33 & 1.11 & 1.09 & 1.06 & 1.11 & 1.09 & 17 & 1.21 & 2 & 1.11 & 99 & 1.15 \\
\hline ITA & & 1.16 & 16 & .31 & 1.29 & $2 L$ & 1.28 & 1.22 & 1.19 & 1.1 & 17 & 1.15 & 1.12 & 1.20 \\
\hline LVA & 5 & 1.12 & 1.11 & 1.51 & 1.40 & 1.40 & 1.38 & 1.49 & 1.64 & 1.48 & 1.54 & 1.38 & 1.38 & 1.38 \\
\hline ROU & 5 & 1.16 & 1.45 & 1.68 & 1.24 & 1.24 & 1.97 & 1.7 & 1.47 & 1.4 & 1.54 & 1.41 & 1.41 & 1.46 \\
\hline LTU & 16 & 1.18 & 1.15 & 1.26 & 1.20 & 148 & 1.46 & 16 & 1.99 & 1.3 & .31 & 1.37 & 1.45 & 1.38 \\
\hline LUX & 1.20 & 123 & 1.27 & 127 & 1.21 & 123 & 1.36 & 1. & 1.28 & 12 & 4 & 110 & 1.11 & 1.22 \\
\hline $\mathrm{NL}$ & & 1.13 & 1.14 & 1.17 & 1.13 & & 1 & 1.18 & 1.17 & 1.17 & & 1.16 & 1.14 & 1.16 \\
\hline $\mathrm{P}$ & & 1.71 & 1.20 & 1.22 & 1.39 & 1.35 & 1 & 1.40 & 1.40 & 1.35 & & 1.31 & 4 & 1.37 \\
\hline PRT & 1.27 & 1.26 & 1.25 & 1.67 & 1.7 & 1.2 & 1.41 & 1.4 & 1.38 & 1.3 & 1 & 1.25 & 1.22 & 1.37 \\
\hline SVK & 33 & 1.28 & 1.26 & 1.29 & 1.26 & 1.22 & 1.31 & 1.3 & 1.49 & 1.4 & 1.44 & 1.38 & 1.17 & 1.33 \\
\hline SVN & 27 & 1.28 & 1.27 & 1.56 & 1.54 & 1.48 & 1.55 & 1.4 & 1.44 & 1.42 & 1.36 & 1.28 & 1.26 & 1.40 \\
\hline ESP & 11 & 1.10 & 1.12 & 1.14 & 1.11 & 1.07 & 1.15 & 1.1 & 1.21 & 1.27 & 1.22 & 1.17 & 1.17 & 1.15 \\
\hline SWE & 1.25 & 1.07 & 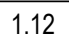 & 1.08 & 1.0 & 1.02 & 1.08 & 1.0 & 1.12 & 1.1 & 1.09 & 1.0 & 1.09 & 1.10 \\
\hline GBR & 25 & 1.24 & 1.22 & 1.19 & 1. & 1.16 & 1.26 & 1.2 & 1.26 & 1.2 & 1.26 & 1.24 & 1.22 & 1.23 \\
\hline
\end{tabular}

Source: own

Note: The short name of each country adopts the three-letter code in accordance with international standards (ISO 3166-1:2006) in the paper. 


\section{Cost of Trade in Services between China and EU Member States}

From Tab. 1, we can find that during 2005-2017 the cost of trade in services between China and most EU member states declined. The cost of trade in services between China and developed countries in the EU is relatively low, such as Germany, Spain, the Netherlands, and so on; and the trade costs with relatively underdeveloped EU member states are higher, such as Lithuania, Latvia, Romania, and so on.

From the perspective of the cost of bilateral service trade with China, the countries with the largest declines were Poland, Ireland and Germany, which fell by $19.48 \%, 14.17 \%$ and $13.79 \%$, respectively. The countries with the largest increases were Lithuania, Latvia and Romania, which rose by $25 \%, 20 \%$ and $12.8 \%$ respectively.

\section{Cost of Service Trade with Different Product Substitution Elasticity}

Regarding the value of the elasticity of substitution across goods $\sigma$, most scholars set it between 5 and 10. Drawing on the practices of Anderson and Wincoop (2004), Shi (2008),
Qian and Liang (2008), it is set to 8 in this study. To investigate the impact of the elasticity of substitution across goods $\sigma$ on service trade cost, the service trade cost is also measured under the condition that the product substitution elasticity is fixed to 5 and 10 . The relevant results are presented in Fig. 2.

From Fig. 2, we can see that when $\sigma$ is 5, 8 or 10 , the scale of service trade costs changes, but the trend of change is not affected, as shown by the fact that the three curves in the figure are basically parallel. This shows that when the elasticity of substitution across goods changes, the trend of service trade costs between China and the EU does not change substantially. Therefore, it can be considered that the elasticity of substitution across goods is not a factor in the cost of service trade. Therefore, what factors will affect the cost of service trade? The remainder of this paper will focus on this issue.

\section{Factors Affecting the Cost of Trade in Services}

According to Anderson's (2004) definition of trade cost and researches by other scholars,

\section{Fig. 2: The cost of trade in services between China and the EU from 2005 to 2017}

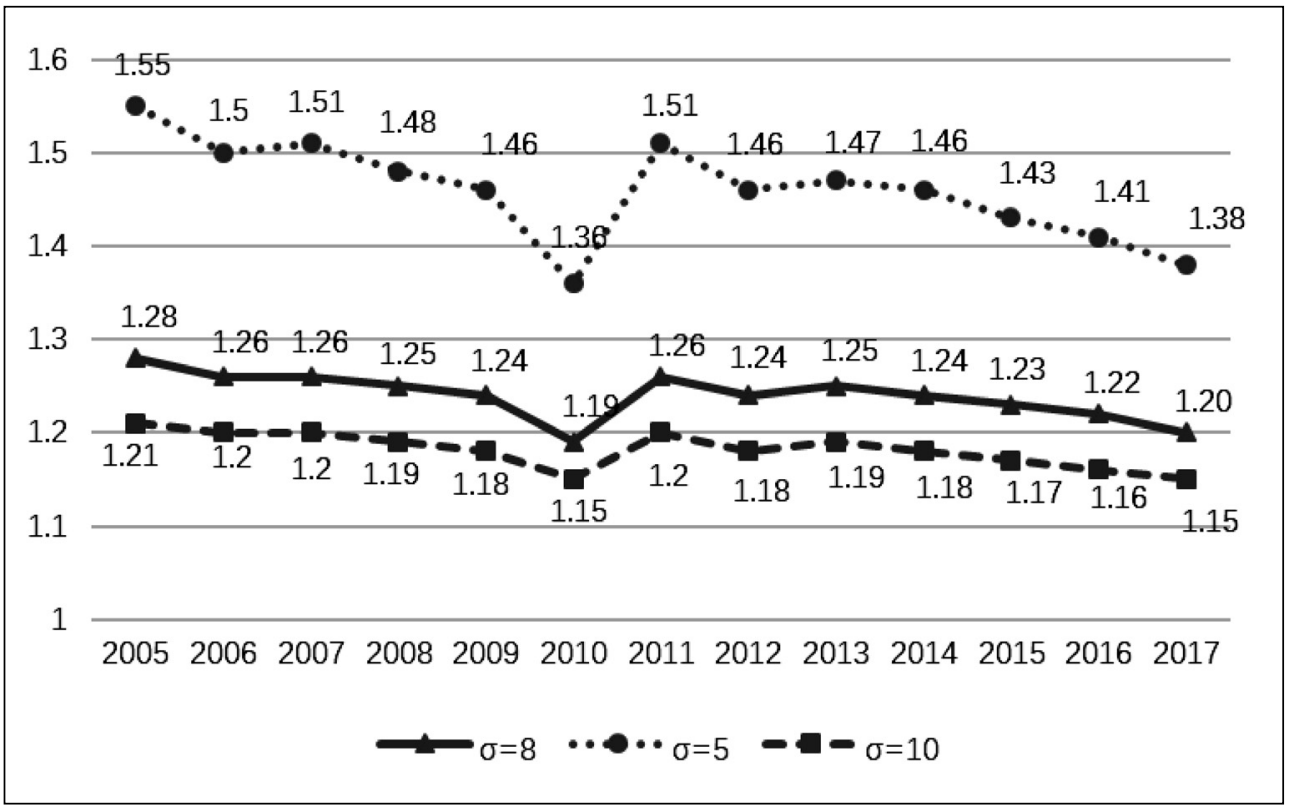


the influencing factors of service trade cost can be divided into spatial distance, economic development level, service restriction, infrastructure and human capital endowment.

\subsection{Spatial Distance}

In the traditional gravity model, spatial distance is considered to be one of the important reasons for the increase or decrease of trade flow, because transportation cost is a part of the trade cost of goods. Similarly, in the research framework of new economic geography, trade costs are considered to be the key to the choice of business location, and the aggregation or diffusion of economic activities (Fujita, 2001). Therefore, trade costs and trade flows are affected by geographical distance. In service trade activities (such as transportation services, education abroad, tourism, etc.), spatial distance also affects the cost of trade.

Therefore, we propose hypothesis 1: Spatial distance has a positive impact on the cost of trade in services. Drawing on the treatment method of Kandilov and Grennes (2010), the geographical distance between the capitals of the two countries is used as a measure of spatial distance.

\subsection{The Economic Development Levels}

According to the Linder Hypothesis, that is, the theory of preference similarity (Linder, 1961), if the economic development levels of the two countries are closer, the possibility of intra-industry trade between the two countries will increase. Income levels are an important indicator of a country's economic development and a major factor in determining the country's demand structure. When the income levels of the two countries are closer, their market demand structure will be more similar, the trade volume between the two countries will increase, and the trade cost will tend to decline.

Therefore, we propose hypothesis 2: The difference in economic level has a positive impact on the cost of trade in services. According to the theory of preference similarity, the per capita gross national income ratio (per capita GNI ratio) is chosen as an indicator to measure the difference in economic levels between countries.

\subsection{Service Restriction}

Service restrictions refer to barriers to trade in services arising from a country's restrictions on certain services in other countries or the manner in which they are provided. It will lead to narrower service channels and market segments, thus reducing the amount of trade in services and increasing the cost of service trade.

Based on the explanations mentioned above, we propose hypothesis 3: Service restrictions have a positive impact on service trade costs. Drawing on the recommendations of Tu (2016), we select service trade openness as a surrogate indicator of service limitations. The openness of trade in services is expressed as the ratio of total trade in services to the country's GDP.

\subsection{Infrastructure}

According to the new factor theory of international trade, infrastructure, which facilitates the flow accumulation, and cultivation of elements, is necessary for a country to carry out trade activities. Infrastructure can directly affect the accumulation of factors in fixed assets, improve the service function of infrastructure, and reduce the production and transaction costs in the trade process. A well-developed public infrastructure saves inventory management costs and helps companies adjust production factors in a timely manner based on market demand, thereby reducing adjustment costs in the trade process (Serrano, 2002; Shirley \& Winston, 2004). Information infrastructure can accelerate information interaction, increase transaction efficiency, reduce communication costs in the trade process, and expand the range of traded goods and the scope of trading countries (Donaubauer, 2018).

Based on the two aspects mentioned above, we propose hypothesis 4: Infrastructure has a negative impact on service trade costs. Drawing on Limao and Venables (2001) and Francois and Manchin (2007), railway density, Internet users and urbanization rate are selected as indicators for measuring infrastructure.

\subsection{Human Capital Endowment}

The export sector of trade in services usually undergoes a shift from the traditional to the modern service trade industry and the human capital-intensive service industry becomes the main carrier of service trade exports. According to factor endowment theory, countries with relatively strong human capital have comparative advantages in human capital- 
intensive industries. Costinot (2009) argued that the increase in the stock of human capital will help accelerate the upgrading and application of technology, deepen the division of labor and improve production efficiency, thereby reducing the cost of trade in services.

Therefore, we propose hypothesis 5: Human capital endowment has a negative impact on the cost of service trade. Regarding the choice of metrics for human capital endowment, we use the education rate (university or above).

\section{Empirical Analysis}

\subsection{Model Setting and Variables}

New trade theory posits that the exports of enterprises are characterized as continuous. Therefore, the cost of service trade in this period may be affected by the previous period. If this feature is not considered when building the model, it will cause bias in the model estimation results. In order to establish a dynamic panel data model, the lag variable of the previous export trade cost of service trade between China and its trading partners is included in the regression Formula. The advantage is that it can reflect the continuity of the cost of trade in services between China and EU member states. Combined with the analysis of the factors affecting the cost of trade in services mentioned above, the econometric model is set as follows.

$$
\begin{aligned}
& \ln \cos t_{i j t}=\alpha_{0}+\beta \ln \cos t_{i j t-1}+\alpha_{1} \ln \text { dist }_{i j}+ \\
& +\alpha_{2} \ln \left(y_{j t} / y_{i t}\right)+\alpha_{3} \ln \left(\text { open }_{i t} * \text { open }_{j t}\right) \\
& +\alpha_{4} \ln \left(\text { tra }_{i t} * t r a_{j t}\right)+\alpha_{5} \ln \left(\text { int }_{i t} * \operatorname{int}_{j t}\right)+ \\
& +\alpha_{6} \ln \left(u r b_{i t} * u r b_{j t}\right)+\alpha_{7} \ln \left(e d u_{i t} * e d u_{j t}\right)+\varepsilon
\end{aligned}
$$

In Formula (11), the subscript $i$ represents China, $j$ represents the EU member state, and $t$ represents time. The explanatory variable is $\cos t$, which represents the cost of service trade between China and EU member states.
In the explanatory variables, dist represents the geographical distance between China and EU member states, replaced by the distance between the capitals of the two countries; $y_{j t} / y_{i t}$ represents the ratio of per capita GNI between EU member states and China during $t$ period. open, tra, int, $u r b$, and $e d u$ represent service trade openness, railway density, number of Internet users per million people, urbanization rate, and education level, respectively.

Since this study examines the bilateral service trade costs of China and EU member states, referring to the method of Tu (2016), the products of open, tra, int, $u r b$, and edu of China and EU member states are taken as corresponding variables. $\varepsilon$ represents the error term. To eliminate the effects of potential heteroscedasticity in Formula (11), we apply logarithmic processing to all variables.

The geographical distance data (variable dist) is taken from the CEPII database. Other variables in Formula (11) are from the World Bank's WDI database.

\subsection{Methodology}

\section{Overall Estimation and Group Estimation}

In the empirical analysis using Formula (11), we use the overall perspective to treat the $\mathrm{EU}$ as a country and examine the factors that determine the cost of trade in services between China and the EU. At the same time, to explain the differences in the factors affecting the cost of trade in services at different stages of economic development, we use Formula (11) for group estimation.

Specifically, the EU member states are divided into three groups according to the per capita national income of each country, namely, the high-income group (GNI per capita is more than 40,000 US dollars), the medium income group (GNI per capita is between 20,000 and 40,000 US dollars), and the low-income group. (GNI per capita is less than $\$ 20,000$ ). The results of the grouping are listed in Tab. 2 .

\section{Tab. 2: Grouping of sample countries}

\begin{tabular}{l|l} 
High income countries & AUT, BEL, DNK, FIN, FRA, DEU, IRL, LUX, NLD, SWE, GBR \\
\hline Medium income countries & CYP, CZE, GRC, ITA, PRT, SVN, ESP \\
\hline Low income countries & BGR, HRV, EST, HUN, LVA, ROU, LTU, POL, SVK \\
\hline
\end{tabular}




\section{Estimation Method}

Formula (11) includes variables that are endogenously related to the cost of service trade, such as the lag of service trade costs, the per capita GNI ratio, and so on. Therefore, it is necessary to consider the endogeneity of the econometric model. Considering the advantages of the system GMM approach, we use it to conduct parameter estimation (Blundell \& Bond, 1998).

The key to application of the GMM is to test whether the residual term has sequence correlation and whether the selection of instrument variables is reasonable. Therefore, the Arellano-Bond Test and Sargan-Test are used to test the model in this study. Meanwhile, stepwise regression is used to test the robustness of the model. The results of parameter estimate of the regression model obtained using Stata13.0 software are organized into Tab. 3 and 4.

According to Tab. 3 and 4 , we find that the $P$ values of Arellano-Bond AR (1) and AR (2) tests of models (a) to $(\mathrm{g})$ are all greater than $10 \%$, which indicates that the test results are not significant. We can therefore conclude that there is no second-order correlation in the residual sequence, whether in the global regression model or the group regression model. The $P$ value of the Sargan-Test is greater than $10 \%$, which indicates that the instrumental variables are not over-identified. In summary, GMM is applicable in models (a) to $(\mathrm{g})$.

\section{Tab. 3: Parameter estimation used by stepwise regression}

\begin{tabular}{|c|c|c|c|c|c|c|}
\hline & (a) & (b) & (c) & (d) & (e) & (f) \\
\hline $\ln \cos t_{i j t-1}$ & $\begin{array}{l}0.433^{* * *} \\
(0.000)\end{array}$ & $\begin{array}{l}0.006^{* * *} \\
(0.000)\end{array}$ & $\begin{array}{l}0.001^{* * *} \\
(0.000)\end{array}$ & $\begin{array}{l}0.002^{* * *} \\
(0.008)\end{array}$ & $\begin{array}{l}0.002^{* * *} \\
(0.000)\end{array}$ & $\begin{array}{l}0.003^{* * *} \\
(0.000)\end{array}$ \\
\hline $\ln d i s t t_{i j t}$ & $\begin{array}{c}0.012^{*} \\
(0.264)\end{array}$ & $\begin{array}{l}0.109^{* * *} \\
(0.000)\end{array}$ & $\begin{array}{l}-0.114^{* * *} \\
(0.009)\end{array}$ & $\begin{array}{l}-0.003^{*} \\
(0.324)\end{array}$ & $\begin{array}{l}-0.110^{* *} \\
(0.061)\end{array}$ & $\begin{array}{l}-0.08^{\star *} \\
(0.049) \\
\end{array}$ \\
\hline $\ln \left(y_{j t} / y_{i t}\right)$ & $\begin{array}{l}0.062^{* *} \\
(0.036)\end{array}$ & $\begin{array}{l}0.018^{* * *} \\
(0.001)\end{array}$ & $\begin{array}{l}0.026^{* * *} \\
(0.008)\end{array}$ & $\begin{array}{l}0.08^{* * *} \\
(0.000)\end{array}$ & $\begin{array}{l}0.003^{* * *} \\
(0.000)\end{array}$ & $\begin{array}{l}0.05^{* * *} \\
(0.008)\end{array}$ \\
\hline $\ln \left(\right.$ open $_{i t} *$ open $\left._{j t}\right)$ & & $\begin{array}{l}-0.145^{\star * *} \\
(0.000)\end{array}$ & $\begin{array}{l}-0.144^{* * *} \\
(0.000)\end{array}$ & $\begin{array}{l}-0.144^{* * *} \\
(0.000)\end{array}$ & $\begin{array}{l}-0.144^{* * *} \\
(0.000)\end{array}$ & $\begin{array}{l}-0.144^{* \star *} \\
(0.000)\end{array}$ \\
\hline $\ln \left(\right.$ int $_{i t} *$ int $\left._{j t}\right)$ & & & $\begin{array}{l}-0.002^{* * *} \\
(0.000) \\
\end{array}$ & $\begin{array}{l}-0.003^{*} \\
(0.391) \\
\end{array}$ & $\begin{array}{l}-0.003^{* * *} \\
(0.000)\end{array}$ & $\begin{array}{l}-0.04^{* * *} \\
(0.007)\end{array}$ \\
\hline $\ln \left(t r a_{i t} * t r a_{j t}\right)$ & & & & $\begin{array}{l}-0.0002^{* *} \\
(0.032)\end{array}$ & $\begin{array}{l}-0.001^{* *} \\
(0.039)\end{array}$ & $\begin{array}{l}-0.001^{* *} \\
(0.034)\end{array}$ \\
\hline $\ln \left(u r b_{i t} * u r b_{j t}\right)$ & & & & & $\begin{array}{l}-0.005^{\star *} \\
(0.043)\end{array}$ & $\begin{array}{l}-0.03^{* *} \\
(0.022)\end{array}$ \\
\hline $\ln \left(e d u_{i t} * e d u_{j t}\right)$ & & & & & & $\begin{array}{l}-0.006^{\star *} \\
(0.017)\end{array}$ \\
\hline constant__ & $\begin{array}{l}0.284^{* *} \\
(0.042)\end{array}$ & $\begin{array}{l}0.305^{\star \star \star} \\
(0.001)\end{array}$ & $\begin{array}{l}0.408^{* * *} \\
(0.000)\end{array}$ & $\begin{array}{l}0.458^{* * *} \\
(0.000)\end{array}$ & $\begin{array}{l}0.388^{\star * *} \\
(0.009)\end{array}$ & $\begin{array}{l}0.136^{\star \star *} \\
(0.007)\end{array}$ \\
\hline Sargan test & $(0.165)$ & $(0.283)$ & $(0.467)$ & $(0.358)$ & $(0.637)$ & $(0.635)$ \\
\hline $\begin{array}{l}\text { Arellano-Bond } \\
\text { AR(1) test }\end{array}$ & $(0.241)$ & $(0.132)$ & $(0.259)$ & $(0.275)$ & $(0.128)$ & $(0.119)$ \\
\hline $\begin{array}{l}\text { Arellano-Bond } \\
\text { AR(2) test }\end{array}$ & $(0.324)$ & $(0.483)$ & $(0.391)$ & $(0.514)$ & $(0.535)$ & $(0.659)$ \\
\hline
\end{tabular}




\subsection{Analysis of the Estimated Results Overall Regression Results}

The overall regression results are presented in Tab. 3. As a result of the stepwise regression method, column (a) in Tab. 3 is a basic model for explaining the cost of service trade using the lag phase of service trade cost, geographical distance, and per capita GNI ratio. Columns (b) through (f) respectively represent the results of the estimation based on model (a), adding other explanatory variables one by one.

According to model (f) in Tab. 3, the regression coefficient of the variable $\ln \cos t_{i j t-1}$ is found to be significantly positive. It shows that the lagging variables of the bilateral service trade costs between China and the EU are positively correlated with the current variables.
This means that the dynamic inertia of service trade costs is an important factor in maintaining the cost of bilateral service trade between China and the EU.

The regression coefficient of the variable $\ln \left(y_{j t} / y_{i t}\right)$ is significantly positive, which indicates that the bilateral service trade costs of China and EU member states are positively correlated with the per capita GNI ratio. The policy implication is that the cost of trade in services between China and the EU countries with similar economic levels is low, which verifies the "Lind effect" (hypothesis 3).

The regression coefficient of the variable $\ln \left(\right.$ open $\left._{i t} *_{\text {open }}\right)$, which measures the service restriction, is significantly negative, indicating that the bilateral service trade costs of

\section{Tab. 4: Parameter estimation after grouping samples}

\begin{tabular}{|c|c|c|c|c|}
\hline & $\begin{array}{l}\text { EU } \\
\text { (f) }\end{array}$ & $\begin{array}{l}\text { High income } \\
\text { countries (g) }\end{array}$ & $\begin{array}{c}\text { Median income } \\
\text { countries }(\mathrm{h})\end{array}$ & $\begin{array}{l}\text { Low income } \\
\text { countries (i) }\end{array}$ \\
\hline $\ln \cos t_{i j t-1}$ & $\begin{array}{l}0.003^{* * *} \\
(0.000)\end{array}$ & $\begin{array}{l}0.013^{* * *} \\
(0.000)\end{array}$ & $\begin{array}{l}0.007^{* * *} \\
(0.000)\end{array}$ & $\begin{array}{l}0.015^{\star * *} \\
(0.000)\end{array}$ \\
\hline $\ln d i s t t_{i j t}$ & $\begin{array}{l}-0.08^{\star *} \\
(0.049)\end{array}$ & $\begin{array}{l}-0.001^{* *} \\
(0.031)\end{array}$ & $\begin{array}{l}-0.002^{* * *} \\
(0.001)\end{array}$ & $\begin{array}{l}-0.003^{* * *} \\
(0.007)\end{array}$ \\
\hline $\ln \left(y_{j t} / y_{i t}\right)$ & $\begin{array}{c}0.05^{* * *} \\
(0.008)\end{array}$ & $\begin{array}{l}0.07^{* * *} \\
(0.004)\end{array}$ & $\begin{array}{c}0.03^{* *} \\
(0.029)\end{array}$ & $\begin{array}{c}0.06 \\
(0.52)\end{array}$ \\
\hline $\ln \left(\right.$ open $_{i t} *$ open $\left._{j t}\right)$ & $\begin{array}{l}-0.144^{\star * *} \\
(0.000)\end{array}$ & $\begin{array}{l}-0.017^{* * *} \\
(0.000)\end{array}$ & $\begin{array}{l}-0.218^{* * *} \\
(0.001)\end{array}$ & $\begin{array}{l}-0.273^{* * *} \\
(0.000)\end{array}$ \\
\hline $\ln \left(\right.$ int $_{i t} *$ int $\left._{j t}\right)$ & $\begin{array}{l}-0.04^{* * *} \\
(0.007)\end{array}$ & $\begin{array}{l}-0.06^{* * *} \\
(0.003)\end{array}$ & $\begin{array}{l}-0.03^{* *} \\
(0.027)\end{array}$ & $\begin{array}{l}-0.01 \\
(0.625)\end{array}$ \\
\hline $\ln \left(t r a_{i t} * t r a_{j t}\right)$ & $\begin{array}{l}-0.001^{* *} \\
(0.034)\end{array}$ & $\begin{array}{l}-0.003^{* * *} \\
(0.008)\end{array}$ & $\begin{array}{l}-0.02^{* *} \\
(0.042)\end{array}$ & $\begin{array}{l}-0.01 \\
(0.726)\end{array}$ \\
\hline $\ln \left(u r b_{i t} * u r b_{j t}\right)$ & $\begin{array}{l}-0.03^{* *} \\
(0.022)\end{array}$ & $\begin{array}{l}-0.02^{* *} \\
(0.041)\end{array}$ & $\begin{array}{l}-0.04^{* *} \\
(0.034)\end{array}$ & $\begin{array}{l}-0.06 \\
(0.573) \\
\end{array}$ \\
\hline $\ln \left(e d u_{i t} * e d u_{j t}\right)$ & $\begin{array}{l}-0.006^{* *} \\
(0.017)\end{array}$ & $\begin{array}{l}-0.01^{* * *} \\
(0.000)\end{array}$ & $\begin{array}{l}-0.005^{\star *} \\
(0.039)\end{array}$ & $\begin{array}{l}-0.004 \\
(0.628)\end{array}$ \\
\hline constant__ & $\begin{array}{l}0.136^{\star * *} \\
(0.007)\end{array}$ & $\begin{array}{l}0.195^{\star * *} \\
(0.005)\end{array}$ & $\begin{array}{l}0.384^{* * *} \\
(0.000)\end{array}$ & $\begin{array}{l}0.283^{* * *} \\
(0.004)\end{array}$ \\
\hline Sargan-Test & $(0.635)$ & $(0.746)$ & $(0.647)$ & $(0.685)$ \\
\hline Arellano-Bond AR(1) test & $(0.119)$ & $(0.368)$ & $(0.293)$ & $(0.341)$ \\
\hline Arellano-Bond $\mathrm{AR}(2)$ test & $(0.659)$ & $(0.594)$ & $(0.653)$ & $(0.416)$ \\
\hline
\end{tabular}

Source: own elaboration

Note: (i) ${ }^{*},{ }^{* *}$ and ${ }^{* * *}$ indicate that the parameter is significant at the significance level of $10 \%, 5 \%$ and $1 \%$, respectively. (ii) The number in parentheses is the $p$ value. 
China and EU member states are negatively correlated with the openness of service trade. The higher the openness of trade in services, the fewer service restrictions, and the lower the cost of service trade. Hypothesis 3 is therefore confirmed.

The regression coefficients of variables such as Internet users $\ln \left(\right.$ int $_{i t} *$ int $\left._{j t}\right)$, railway density $\ln \left(t r a_{i t} * t r a_{j t}\right)$ and urbanization $\ln \left(u r b_{i t} * u r b_{j t}\right)$ are negative. It shows that the cost of bilateral service trade between China and EU member states is negatively related to infrastructure construction. This indicates the popularity of Internet applications, the optimization of railway networks and the improvement of urbanization, innovating the content and methods of international service trade, improving trade efficiency and thus reducing the cost of service trade.

The regression coefficient of the education rate used to measure human capital endowment is negative, indicating that the bilateral service trade cost is negatively correlated with human capital. It means that the increase in education rate will lead to the improvement of human capital endowment, promote the development of human capital-intensive service trade, and help reduce the bilateral cost of service trade.

From the absolute value of the regression coefficient, the variable with the largest coefficient is service trade openness, with a value of -0.144 ; the second is the per capita GNI ratio, with a value of 0.05 . It is obvious from Tab. 3 that the service trade openness, the ratio of per capita GNI and the number of Internet users are the main factors affecting the cost of service trade.

\section{Model Estimation Results for Sample Grouping}

The models $(\mathrm{g})$ to (i) in Tab. 4 are the results of regression estimation after grouping the samples. For comparison, we also included ungrouped regression estimates in the Tab. 4 .

According to the parameter estimation results in Tab. 4, the regression coefficient of the variable $\ln \left(y_{j t} / y_{i t}\right)$ in model (i) is not significant, but it is significant in models (g) and $(h)$. It shows that when there is trade in services between China and the relatively underdeveloped EU member states, the income gap between countries will not affect the cost of service trade. The reason may be that China has a greater similarity with the economic structure of these countries.
The regression coefficients of variables such as the number of Internet users, railway density, and urbanization cannot pass the significance test in model (i). This is due to the fact that infrastructure construction in the lowincome group is still insufficient, and the longterm positive effect of infrastructure has not been fully reflected.

The regression coefficient of the variable $\ln \left(\right.$ open $_{i t} *$ open $\left._{j t}\right)$ is larger in models (h) and (i), which indicates that for the EU member countries of the median and low income groups, the service restriction can affect the cost of trade in service between them and China.

In models (g) and (h), the regression coefficient of the variable $\ln \left(e d u_{i t} * e d u_{j t}\right)$ is statistically significant, does not pass the significance test in model (i). It means that the impact of human capital endowment on the cost of service trade is heterogeneous among countries with different levels of economic development. This can be explained in two ways: (i) the dominant role of service trade in low-income countries is still the traditional sector, (ii) the lack of human capital investment leads to a lack of human capital endowment in low-income countries.

\section{Conclusions and Recommendations}

\subsection{Conclusions}

Based on the estimation of the cost of bilateral service trade between China and EU member states, this study empirically analyzes the factors affecting service costs from the perspective of the entire sample and various groups. The main conclusions are as follows.

First, the service trade costs of China and EU member states are generally declining, and there is significant potential for further decline. In addition, the costs between China and the developed countries of the EU are generally low, while those between China and the underdeveloped countries of the EU are higher.

Second, from the results of the empirical model, service trade openness, per capita GNI ratio and Internet users are the most significant in terms of service trade cost, while railway density, urbanization rate, and education rate also have certain influence on service trade cost. Distance is no longer the main factor affecting the cost of service trade.

Third, there are differences in influencing factors among countries with different level of 
economic development. Between China and high-income countries of the EU, infrastructure and human capital endowments are important factors influencing the cost of bilateral service trade, and the per capita GNI ratio has a significant positive effect on service trade costs, but these conclusions do not hold for China and low-income EU member states. Compared with the EU countries in the highincome group, service restrictions have a greater impact on the cost of bilateral service trade in the medium and the low-income groups.

\subsection{Recommendations}

To reduce the cost and expand the scale of service trade between China and EU countries, based on the above analysis, this study puts forward the following recommendations.

First, the policy barriers to trade in services need to be eliminated, and the degree of liberalization of international trade in services should be greatly improved. Each country needs to increase the openness of the service trade market, improve the service trade cooperation mechanism through multilateral and bilateral consultations and negotiations, and form a consensus on the service trade tariff policy.

Second, each country should develop a focus on the development of service trade in line with the country. For countries with relatively developed economies, more attention should be paid to human capital investment, the development of human capital and knowledgeintensive service industries should be vigorously promoted, and bilateral service trade should be conducted with China in the fields of finance, communications, scientific research and technical services. For countries with relatively less developed economies, trade with China should be vigorously developed in laborintensive service sectors with technological advantages.

Finally, each country should improve service trade infrastructure and increase support for new industries, technologies, and formats of service trade. To improve transaction efficiency in service trade, the investment in transportation infrastructure such as railways, highways, ports and airports, and telecommunications infrastructure should be increased. The government should promote the integration of the Internet and service trade and support the development of service trade platform. In particular, China and the EU should encourage enterprises to engage in international cross-border e-commerce cooperation, establish new methods of cooperation in the fields of tourism, information services, education and training, and realize the sharing and complementary advantages of service trade resources.

This paper is supported by the Major Project of National Social Science Fund of China (No. 16ZDA053) and the First Class Discipline of Zhejiang-A (Zhejiang Gongshang UniversityStatistics).

\section{References}

Ablaiti, Y. M. (2013). Research on the Cost Measurement Method of China's Export Trade. Inquiry Into Economic Issues, (4), 160-166. http://doi.org/10.13516/j.cnki.wes.2013.05.005

Anderson, J. E., \& van Wincoop, E. (2003). Gravity with Gravitas: A Solution to the Border Puzzle. Social Science Electronic Publishing, 93(1), 170-192. http://doi.org/10.3386/w8079

Anderson, J. E., \& van Wincoop, E. (2004). Trade cost. Journal of Economic Literature, 42(3), 691-751. http://doi. org/10.1257/0022051042177649

Armington, P. S. (1969). A Theory of Demand for Products Distinguished by Place of Production. IMF Economic Review, 16(1), 159-178. http://doi.org/10.2307/3866403

Blundell, R., \& Bonds, S. (1998). Initial conditions and moment restrictions in dynamic panel data models. Economics Papers, 87(1), 115-143. http://doi.org/10.1016/S03044076(98)00009-8

Bobowski, S. (2018). Measurement of Intra-Industry Trade in International Production Networks in The HDD Industry. The Case of East Asia. Transformations in Business \& Economics, 17(2A), 390-409.

Costinot, A. (2009). On the Origins of Comparative Advantage. Journal of International Economics, 77(2), 255-264. http://doi.org/10.1016/j.jinteco.2009.01.007

Donaubauer, J., Glas, A., Meyer, B., \& Nunnenkamp, P. (2018). Disentangling the impact of infrastructure on trade using a new index of infrastructure. Review of World Economics, 154(4), 745-784. http://doi. org/10.1007/s10290-018-0322-8

Drelich-Skulska, B., \& Domiter, M. (2018). Protectionism in Trade Policy in XXI Century. 
Transformations in Business \& Economics, 17(2A), 353-371.

Francois, J., \& Manchin, M. (2013). Institutions, Infrastructure, and Trade. World Development, 46, 165-175. http://doi.org/ 10.1016/j.worlddev.2013.02.009

Fujita, M., Krugman, P., \& Venables, A. J. (2001). The Spatial Economy: Cities, Regions, and International Trade. MIT Press Books, 1(1), 283-285. http://doi.org/10.1111/1467-8276.t01$1-00065$

Gervais, A. (2018). Estimating the impact of country-level policy restrictions on services trade. Review of International Economics, 26(4), 743-767. http://doi.org/10.1111/roie.12340

Kandilov, I. T., \& Grennes, T. (2010). The determinants of service exports from Central and Eastern Europe. Economics of Transition, 18(4), 763-794. http://doi.org/10.1111/j.14680351.2010.00392.x

King, Y. S. (2018). International Service Trade of East Asian Region: Factors Influence on the Share. Asia-pacific Journal of Multimedia Services Convergent with Art, Humanities, and Sociology, 8(11), 157-169. http://doi. org/10.21742/AJMAHS.2018.11.20

Limao, N., \& Venables, A. J. (2001). Infrastructure, Geographical Disadvantage, Transport Costs and Trade. World Bank Economic Review, 15(3), 451-479. http://doi. org/10.1596/0-1985-0908-1

McCallum, J. (1995). National Borders Matter: Canada-U.S. Regional Trade Patterns. The American Economic Review, 85(3), 615-623. http://doi.org/10.2753/PET1061-1991380390

Munir, K., \& Ameer, A. (2018). Effect of economic growth, trade openness, urbanization, and technology on environment of Asian emerging economies. Management of Environmental Quality, 29(6), 1123-1134. https://doi.org/10.1108/MEQ-05-2018-0087

Nordas, H. K. (2018). What drives trade in services? Lessons from the Nordics. Applied Economics, 50(33), 3532-3545. http://doi.org/ 10.1080/00036846.2018.1430334

Novy, D. (2006). Is the Iceberg Melting Less Quickly? International Trade Costs after World War II. The Warwick Economics Research Paper Series (TWERPS). http://doi. org/10.2139/ssrn.944421

Novy, D. (2013). Gravity Redux: Measuring International Trade Costs with Panel Data. Economic Inquiry, 51(1), 101-121. http://doi. org/10.1111/j.1465-7295.2011.00439.x
Qian, X. F., \& Liang, Q. (2008). Measuring the Bilateral Trade Costs between China and G-7: A Revised Gravity Model. The Journal of Quantitative \& Technical Economics, (2), 53-62. http://doi.org/10.13653/j.cnki.jqte.2008.02.009

Radukic, S., Mastilo, Z., Kostic, Z., \& Vladusic, L. (2019). Measuring of The Goods and Labor Markets Efficiency: Comparative Study of Western Balkan Countries. Montenegrin Journal of Economics, 15(2), 95-110. https://doi.org/10.14254/1800-5845/2019.15-2.8

Robinson, S., Wang, Z., \& Martin, W. (2002). Capturing the Implications of Services Trade Liberalization. Economic System Research, 14(1), 3-33. http://doi. org/10.1080/09535310220111806

Rose, A. K., Lockwood, B., \& Quah, D. (2000). One Money, One Market: Estimating the Effect of Common Currencies on Trade. Economic Policy, 15(30), 7-45. http://doi. org/10.2307/1344722

Serrano, R. M., López-Bazo, E., \& Artís, M. (2002). Public Infrastructure and the Performance of Manufacturing Industries: Short-and Long-run Effects. Regional Science and Urban Economics, 32(1), 97-121. http://doi.org/10.1016/S0166-0462(00)00058-2

Shi, B. Z. (2008). The Measurement of Trade Cost between China and Its Main Trade Partners - Based on the Revised Gravity Model. Journal of International Trade, (11), 24-30. http://doi.org/10.13510/j.cnki.jit.2008.11.013

Shirley, C., \& Winston, C. (2004). Firm Inventory Behavior and the Returns from Highway Infrastructure Investment. Journal of Urban Economics, 55(2), 398-415. http://doi. org/10.1016/j.jue.2003.11.001

Skulski, P. (2018). Does China Pose a Threat to Global Security? Transformations in Business \& Economics, 17(2A), 372-389.

Tao, H. J., Luckstead, J., Zhao, L., \& Davis, C. G. (2017). Is pork trade good for China's greenhouse gas emission. Chinese journal of population, resources and environment, 15(4), 301-311. https://doi.org/10.1080/10042857.20 17.1405517

Tu, Y. F. (2016). The Measurement and Determinants of the Costs in China's Bilateral Service Trade. International Business, 11, 17-27. http://doi.org/10.13509/j.cnki. ib.2016.01.002

Wan, H. Y., \& Rao, Y. Y. (2017). Influencing Factors Measurement of China's Bilateral Service Trade Costs Based on Novy 
Model. Journal of Heilongjiang University of Technology (Comprehensive Edition), 17(12), 80-86. http://doi.org/10.16792/j.cnki.16726758.2017.12.016

Weiss, J. (2010). Changing Trade Structure and Its Implications for Growth. World Economy, 33(10), 1269-1279. http://doi.org/10.1111/ j.1467-9701.2010.01281.x
Zhang H., \& Jiang, L. H. (2019). Measurement of Bilateral Services Trade Cost and Decomposition of Services Trade Growth: Based on Panel Data of China and 21 OECD Countries. International Business Research, 40(4), 14-25. http://doi.org/10.13680/j.cnki. ibr.2019.04.002 